\title{
Олександр Юдін
}

\section{ЕСТЕТИКА ГЕРМАНА КОГЕНА Й ЕСТЕТИКА МИХАЙЛА БАХТІНА: ПЕРЕОСМИСЛЕННЯ ПОНЯТТЕВИХ ЗАПОЗИЧЕНЬ}

Рання філософія й естетика Михайла Бахтіна була однією з найцікавіших спроб подолання трансценденталізму в європейській філософії. Зокрема, це рельєфно виявляє себе у порівнянні з філософією та естетикою Германа Когена, лідера марбурзької школи неокантіанства, що справила суттєвий вплив на формування бахтінської думки ${ }^{1}$.

Мета філософії Когена - окреслити і сконструювати єдність культурної свідомості [Renz, 2006: p. 327]. Філософія Когена - це філософія свідомості. Свого часу ще перший російський філософ-неокантіанець Борис Фохт зазначав, що «у Когена на перший план з усією енергією висувається саме термін свідомості» [Фохт, 2003: с. 250]. Ця думка закріпилася також в європейській історії філософії [Copleston, 1994: p. 362]. В останні десятиліття інтерес до філософії Когена зростає. Деякі сучасні дослідники намагаються звільнити ії від звинувачень в обмеженні філософії наукою (що закріпилося за нею зусиллями Мартина Гайдегера та Юліуса Ебінгауза) й від сприйняття як дещо схоластичної, навіть говорять про «нове відкриття» філософії Когена [див.: Poma, 1997: p. ix; 2006: p. х]. Проте розуміння іiі як ідеалістичної залишається в силі, iii самовизначення як філософії критичного ідеалізму не піддається сумніву.

Можна сказати, що філософія Когена знає буття тільки як предмет свідомості, а тому лишається суто в межах суб'єкт-об'єктної парадигми.

Коген, як послідовник Канта, виявляє себе систематиком. Його версія системи, як і кантівська, складається з трьох частин: «Логіка чистого пізнання», «Етика чистої волі» та «Естетика чистого почуття». Інакше кажучи, він прагне вибудувати систему ще більш систематичну, або, сказати б, ще «чистішу», ніж кантівська. Естетика в цьому сенсі постає як «третій член системи філософіï» [Cohen, 1912: S. xi]. Ї̈ї призначення полягає передовсім у тому, щоб завершувати систему філософії [див.: Renz, 2006: p. 334]. I сама філософська естетика визначається Когеном «як систематична естетика» [Cohen, 1912: S. xi]. Систематичність тут можна розуміти у подвійному

(C) О. Юдін, 2014

${ }^{1}$ Про вплив неокантіанства й, зокрема, Когена на Бахтіна писали неодноразово [див.: Исупов, 1990: c. 30, 37; Каган, 1991: с. 17; Пул, 1997; Пуль, 1995; Brandist, 2002: p. 13-14; Clark, 1984: p. 1; Coates, 1999: p. 26; Holquist, 2002: p. 4-6]. В Марбурзькому університеті навчався один із близьких друзів Бахтіна М.І. Каган, який разом з ним входив до так званого «невельского кола», тобто філософського семінару, який неофіційно називали «кантівським» [Каган, 2010: с. 37]. 
сенсі, як обгрунтування, по-перше, єдності мистецтва, по-друге, єдності філософії [Poma, 1997: p. 132].

Це зумовлює значною мірою зовнішній, можна сказати, упереджений підхід до мистецтва. Коген принципово відокремлює філософську естетику від мистецтвознавства [Cohen, 1912: S. XI]. Його естетика - не стільки осмислення конкретної мистецької практики, скільки проекція на неї філософських принципів. Навіть прихильні до Когена дослідники визнають, що останній «знаходить у творі мистецтва те, що сам вкладає в нього» [Рота, 2006: p. 146]. Це не означає його нечутливості до мистецтва. Його справді величезна двотомна естетика (загалом майже дев'ятсот сторінок) містить чимало цікавих аналізів творів різних видів мистецтва. Однак головною турботою Когена лишається систематизація понять: чистоти естетичної свідомості, законів чистого почуття, естетичної закономірності як такої, будови естетичної свідомості, прекрасного, піднесеного, гумору (останні три поняття є, за Когеном, основними категоріями естетики) тощо [див. Cohen, 1889: S. 144f., 222f.; Cohen, 1912: розд. 3, 4, 5 відповідно].

Б.О. Фохт узагальнював завдання естетики Когена так: «... вже у Канта в “Критиці здатності судити" і ще більше в Когена в “Естетиці чистого почуття" все зводиться до того, щоб відкрити, визначити й обгрунтувати поняття естетичної закономірності в іії зв'язку, відповідності, своєрідній відмінності й водночас внутрішній подібності з поняттям закономірності взагалі як загальної бази й принципу всієї трансцендентальної філософії» [Фохт, 2003: с. 213].

Відштовхуючись від Кантового трансцендентального методу, Коген прагне сформулювати логічні засади духовної діяльності людини i, зокрема в естетиці, намагається визначити умови можливості чистого почуття або ж умови «можливості естетичної свідомості та предмета для естетичної свідомості» [Cohen, 1912: S. 84].

Ці риси визначають суттєву відмінність Когена від Бахтіна, головним поняттям філософії якого є поняття «буття-події». 3 точки зору Бахтіна, філософія Когена також страждає на «теоретизм» ${ }^{2}$. Інакше кажучи, філософія Когена принципово лишається в рамках суб'єкт-об'єктного підходу, де в понятті суб'єкта не розрізнені людство й індивід.

Проте очевидно, що певні положення естетики Когена і кантівської традиції філософії загалом вплинули на бахтінську естетику. Зокрема, у ній зберігається положення Когена про естетичну активність свідомості як щось первинне, що не може висновуватися 3 інших логічних або історичних передумов. Наприклад, Коген говорить про «розум мистецтва» як первинне (Ursprünglich) у душі [див.: Cohen, 1912: S. 70-71]. Також у філософії й естетиці Бахтіна важливим інструментом є поняття цінності, що прийшло з неокантіанської традиції [див.: Столович, 1989]. Хоча естетика Когена є естетикою однієї свідомості, в інших працях в нього з'являються роздуми про відношення я та іншого ${ }^{3}$. Також у Бахтіна зберігається залежність від кантівської тріади

2 «Теоретизм» - принципове бахтінське поняття критичного спрямування, яке він застосовує майже до всієї попередньої, насамперед класичної філософії. Хоча загальне визначення теоретизму у Бахтіна відсутнє, воно цілком зрозуміло з декількох часткових визначень. Теоретизм це намагання звести, «прилучити», як каже Бахтін, реальний світ вчинку до теоретичного світу, сконструйованого з наукових або філософських понять. Тобто теоретизм - це редукціонізм [див.: Бахтин, 2003: с. 15-17, 23-24, 28].

${ }^{3}$ Див.: Каган, 1991: с. 17. Це навіть дає підставу сучасним дослідникам розглядати Когена в традиції філософії діалогу [Сокулер, 2008]. 
філософських дисциплін i, відповідно, царин буття та трьох способів ставлення суб'єкта до дійсності - царини пізнання, тобто теоретичного ставлення до світу, царини практичної або моральної філософії та царини естетики. Розуміння ключових для бахтінської естетики понять змісту (як дійсності пізнання і вчинку) та форми (як естетичного оформлення дійсності пізнання і вчинку) [Бахтин, 2003: с. 289] також зумовлене кантівським розрізненням форми і змісту в діяльності споглядання.

Та найважливішим, на нашу думку, $є$ те, що саме в Германа Когена Бахтін запозичив одне з ключових понять своєї естетики, а саме поняття завершення [Cohen, 1912: S. 209] (що увійшло до сучасного естетичного та літературознавствчого дискурсу саме через бахтінську естетику), точніше, конфігурацію понять завершення та естетичної любові ${ }^{4}$. Проте принципово важливими є саме відмінності. Порівняння позицій Когена й Бахтіна уочевиднює, що завдяки опорі на феноменологічний метод, з одного боку, відбувається подолання Бахтіним традиції трансцендентальної філософії, а з іншого, все ж зберігається певна залежність від неї.

Як послідовник Канта, Коген намагається виснувати естетичну діяльність зі самої лише свідомості. І оскільки апріорі для нього є головним поняття чистого почуття (отриманий від Канта імпульс до обов'язкової побудови системи), він пропонує емпіричне наповнення цієї здатності трансцендентальної суб'єктивності. Таким емпіричним наповненням постає любов як афект, що долає свою афективну природу: «Любов - це афект, який не тільки слугує передумовою для естетичного почуття, але й перетворюється на естетичне почуття; який у цьому перетворенні досягає чистоти естетичного почуття» [Cohen, 1912: S. 174-175]. Імовірно, естетична любов у Когена відіграє таку важливу роль, оскільки вона є водночас емпіричним i «чистим» почуттям: «... якщо естетична свідомість має бути визначена як чисте почуття, то це чисте почуття є любов і це означає, що любов... є першоджерелом мистецтва» [Cohen, 1912: S. 178].

Також поняття естетичної любові спирається у марбурзького мислителя на певну історичну аргументацію. Інша людина, що є об’єктом естетичного почуття, естетичної любові й, відповідно, завершення, фактично розглядається лише як тіло. Когена здебільшого цікавить питання про естетичну діяльність як подолання «тваринного» ставлення до тіла іншої людини, і він намагається визначити зв'язок між античним і християнським мистецтвом. Саме поняття естетичної любові й постає тут спільним знаменником між давньогрецьким Еросом і християнською любов'ю: «... не ідеал Фідія є останнім кроком мистецтва, і зокрема у християнському мистецтві саме любов має стати центральною проблемою» [Cohen, 1912: S. 176].

Поняття завершення (Vollendung) в Когена $\epsilon$ похідним у тому сенсі, що розвиває естетичну концепцію, в якій центральним поняттям $\epsilon$ поняття естетичної любові: «В поєднанні любові й поваги (Ehre) знаходить своє завершення (vollendet sich) поняття любові... Це завершення любові, на основі піднесення через афект поваги, здійснює лише мистецтво» [Cohen, 1912: S. 178].

Отже, завершення постає як продукт, корелят і водночас критерій естетичної любові і відтак чистого естетичного почуття. Ті конкретні аналізи, які наводяться у Когена як ілюстрація реалізації естетичної любові, мають на увазі образ людини як тіла, тобто як природної реальності, і завершення тут означає подолання ізольовано-

${ }^{4}$ На цей факт, здається, першими звернули увагу і чітко зафіксували коментатори тексту «Автор і герой в естетичній діяльності» [Бахтин, 2003: с. 597-600]. 
сті окремої людини і включення ії (насамперед тіла) в цілісне бачення (знову ж таки мається на увазі ціле природи):

«Ми потребуємо почуття як методичної чистоти. Відповідно, у справжньому мистецтві ми пізнаємо тенденцію до завершення (Vollendung ${ }^{5}$ ) як його критерій. Це тенденція до цілісності (Ganzheit) та єдності (Einheit), що відкидає окреме, ізольоване, яке постає для периферійних точок зору, але не для центральної. Завершеність $\epsilon$ тотальністю (Allheit); тому вона поглинає все окреме, ніщо не залишаючи поза своєю увагою... Тут також дається взнаки любов, що приймає в себе найменші деталі, освітлює й одухотворює найменшу рису» [Cohen, 1912: S. 184-185].

А ось доволі близьке висловлювання у Бахтіна, де також присутні ці поняття: «Звідси безпосередньо випливає також загальна формула основного естетично продуктивного ставлення автора до героя - відношення напруженого позазнаходження автора стосовно всіх моментів героя, просторового, часового, ціннісного й смислового позазнаходження, що дозволяє зібрати всього героя, який зсередини себе самого є розсіяним і розкиданим у заданому світі пізнання і відкритої події етичного вчинку, зібрати його та його життя й виповнити до цілого тими моментами, які для нього самого в ньому самому є недоступними» [Бахтин, 2003: с. 96]. Тож, як бачимо, наявні значні збіги у формулюваннях: так само йдеться про досягнення цілісності, єдності, навіть подолання периферійних точок зору (це формулювання, яке натякає на бачення і відповідно якусь тенденцію до феноменологічного підходу, щоправда, у Когена лишається поодиноким і нерозгорнутим).

Проте водночас поняття завершення в Когена за своїм змістом значно відрізняється від бахтінського. Насамперед найбільш впадає в око головна відмінність, яка полягає у тому, що в Когена як у кантіанця взагалі відсутнє поняття про другу свідомість. Естетична подія у Бахтіна розгортається саме між двома свідомостями. Авторська свідомість обіймає свідомість героя. Важливу, хоча й обмежену, роль у нього відіграє поняття вживання («вживания», «вчувствования»), що походить від поняття розробленого також німецькою філософською естетикою - Einfühlung 6 . Коген дуже коротко розглядає поняття вживання у своїй «Естетиці чистого почуття», власне, тільки для того, щоб піддати його критиці як нетворче, як почуття, що не $є$ продуктивним і не відповідає методичному ідеалу чистого почуття: «Чисте почуття є не вживання, а чуйність (Erfühlung), причому для обох сторін, як для об'єкта, так і для суб'єкта». Вживання взагалі, на його думку, не є проблемою для естетики, воно є лише моментом, що має місце на «відносних ступенях почуття» $\mathrm{i}$ далі «зазнає розпаду» [Cohen, 1912: S. 185-186]. 3 цих формулювань видно, що Коген взагалі мислить естетичне відношення як суб'єкт-об'єктне, тоді як у Бахтіна воно постає як суб'єкт-суб'єктне, адже герой для нього - насамперед суб'єкт [Бахтин, 2003: с. 165]. Водночас Бахтін також піддає критиці абсолютизацію вживання,

${ }^{5}$ Варто зауважити, що в цьому і в деяких інших контекстах поняття Vollendung Когена можна також перекладати як «досконалість». Воно зберігає в нього обидва значення: завершення в сенсі включення в тотальність, подолання окремішності, й досконалість тіла, особливо в тих випадках де йдеться про скульптурне чи живописне зображення останнього. У Бахтіна це друге значення повністю відсутнє. Натомість у ставленні до тіла в нього взагалі відсутні античні мотиви, Ерос, його подолання, і тіло постає тільки крізь призму християнського бачення.

${ }^{6}$ Поняття вживання (Einfühlung) відіграє важливу роль у німецькій філософській естетиці і, як відзначає сам Бахтін, найбільш глибоко було розроблено німецьким філософом Теодором Ліппсом [див. зокрема: Бахтин, 2003: с. 94, 595]. 
намагання звести до нього естетичну діяльність, i, цілком імовірно, що критика Когена сталася тут для нього у пригоді. (Зокрема, саме на Когена він спирається в своїй критиці експресивної естетики, коли аргументує відмінність естетичної любові від вживання [див.: Бахтин, 2003: с. 154].)

Інша суттєва відмінність полягає в тому, що саме поняття завершення стає центральним поняттям естетики Бахтіна, тоді як поняття естетичної любові дещо відступає на другий план. Точніше, Бахтін дуже активно вживає поняття любові (маючи на увазі в підтексті саме естетичну любов), але на відміну від Когена, який активно й методично категоризує, пояснює його за допомогою логічних дефініцій, російський мислитель останніх майже уникає.

Поняття любові взагалі одне з найуживаніших в тексті Бахтіна, воно, так би мовити, супроводжує поняття завершення, постаючи його синонімом, наповнюючи його живим теплом, але сором'язливо уникає, як сказано, логічної категоризації. Бахтін говорить про «любовне усунення себе 3 поля життя героя», про «милування» («любование») героєм, про «любовне осягнення» меж («границ») героя, про любов як «нове емоційно-вольове ставлення до іншого як такого», про «формотворчу любов матері та інших людей», що йде 3 дитинства, про «естетично продуктивну любов», про «любовне завершення», про беззмістовність та безпредметність чистої (!) любові, «любовне активне створення форми», «любовне споглядання», «внутрішню визначеність» як «освітленість не смислом, а любов'ю поза всяким смислом», про «любовно стверджуючу форму» і таке ін. [Бахтин, 2003: с. 97, 100, 110, 120, 126, 129, 156, 165, 168, 172, $176,187,200,231]$. Можна сказати, що діяльність автора у зображенні Бахтіна просочена поняттям любові. Однак пряме визначення цього поняття знаходимо лише двічі:

«...творча реакція є естетична любов» [Бахтин, 2003: с. 165]; «...любов як активний підхід до іншої людини поєднує зовні пережите внутрішнє життя... із зовні пережитою цінністю тіла в єдину й унікальну людину як естетичне явище, поєднує спрямованість 3 напрямом, кругозір з оточенням» [Бахтин, 2003: с. 155].

В останньому висловлюванні любов постає практично тотожною поняттю завершення, адже вона поєднує обидва вище зазначені етапи естетичної діяльності (вживання і завершення зовні) й обидва кругозори - героя та автора - в єдине ціле («естетичне явище»). Проте ці обидва визначення зустрічаються в русі тексту, в ході розгортання, уточнення думки, але не у відправних чи підсумкових формулюваннях.

Щодо цієї «сором'язливості» відносно дефініцій можна висловити наступне міркування. Не можна не відзначити інший спільний момент наявний в естетичних концепціях обох мислителів, який проте має в них різний смисл. Ідеться про питання зв'язку між естетикою та релігією.

Герман Коген однозначно заперечує значення релігії для мистецтва. На його думку, виводити мистецтво з релігії $є$ методично хибним: «У корні невірною $є$ методика... яка керується поглядом: мистецтво живиться від релігії. Вірним є рівно протилежне: релігія живиться суцільно від мистецтва в тому, що стосується всіх ії змістів та осіб, за допомогою яких вона так чи інакше приводить у дію культ...» ${ }^{7}$ [Cohen, 1912: S. 184].

Тож естетична любов у нього пов'язана з розумінням людини як природної істоти, тобто в сенсі частини природи: «Чисте почуття $є$ чиста любов до природи люди-

7 «Чи потребує мистецтво поняття божества, це велике питання. Цілком можливо, що греки отримали своїх богів завдяки мистецтву, і повсюди мистецтво, ймовірно, було причетним до їх формування» [Cohen, 1912: S. 186]. 
ни, що є частиною загальної природи. Ця любов є справжнім почуттям, творчим почуттям. Без цієї любові мистецтво не могло б з'явитися, і без неї воно не може розвиватися. Вона є рушійною силою (Urkraft) мистецтва, Вона єдино і є любов’ю»; «...чиста продуктивність, в якій реалізується чисте почуття, є любов до природи людини» [Cohen, 1912: S. 182-183]. Отже, концепція Когена відштовхується від античного чи принаймні ренесансного світогляду.

Таке розуміння є у певному сенсі протилежним бахтінському. Розробляючи поняття вчинку в рамках своєї першої філософії («До філософії вчинку»), Бахтін посилається на життя і смерть Христа як модель відповідального вчинку взагалі. В естетиці ця залежність постає ще очевидніше. 3 багатьох непрямих формулювань ясно видно, що Бахтін, запозичуючи в Когена поняття естетичної любові, дуже істотно його переосмислює, і його поняття саме значною мірою живиться від християнської ідеї любові ${ }^{8}$.

Насамперед, поняття естетичної любові у Бахтіна $є$ двостороннім, тобто моя естетична любов до іншого має в ньому відповідник як потребу в цій любові: «...я відчуваю абсолютну нужду в любові, яку тільки інший зі свого унікального місця зовні мене може здійснити внутрішньо; ця нужда, щоправда, розбиває мою самодостатність зсередини, але ще не оформлює мене ззовні» [Бахтин, 2003: с. 129]; «У цьому сенсі можна говорити про абсолютну естетичну потребу людини в іншому, в активності бачення, пам'яті, збирання та об'єднання іншого, що тільки й може створити її зовнішньо закінчену особистість, цієї особистості не буде, якщо іï не створить інший» [Бахтин, 2003: с. 115].

Отже, естетична любов є буттєвою відповіддю на цю абсолютну потребу іншого в мені. I тому для Бахтіна (зокрема, саме у трактаті «Автор і герой в естетичній діяльності», оскільки, наприклад, у «Творчості Франсуа Рабле і народній культурі середньовіччя й Ренесансу» ситуація інша) неприйнятним є когенівське твердження про «любов до природи людини» і також завершення образу людини у сенсі включення у ціле природи як «частини загальної природи», тобто акцент на тілесності людини. Навпаки, тіло для Бахтіна - це образ душі, i, власне, завдання автора полягає в тому, щоб сформувати тіло як образ («лик») душі людини, оскільки сама людина не змозі цього зробити:

«Адже тільки іншого можна обійняти, охопити з усіх боків, любовно відчути всі його межі: тендітна конечність, завершеність іншого, його тут-і-тепер-буття внутрішньо пізнаються мною і ніби оформлюються обіймами... Тільки до уст іншого можна доторкнутися устами, тільки на іншого можна покласти руки, активно піднятися над ним, осіняючи його суціль («осеняя его сплошь») усього, в усіх моментах його буття, його тіло і в ньому душу» [Бахтин, 2003: с. 120; курсив автора, підкреслювання тут і далі моє. - О. Ю.].

Не можна не звернути увагу на вживання слова «осіняти» («осенять») та його похідних: «осеняя», «осенение», «осеняем» ${ }^{9}$. Вони вживаються в трактаті Бахтіна

${ }^{8}$ На християнські мотиви, що лежать у підгрунті естетики Бахтіна дослідники вже неодноразово звертали увагу [див. напр.: Бонецкая, 1994; Исупов, 1990; Исупов, 2010; Фридман, 1992].

9 «Естетична активність моя - не в спеціальній діяльності митця-автора, а в єдиному житті, недиференційованому й не звільненому від неестетичних моментів, - що синкретично таїть у собі ніби зародок творчого пластичного образу, виражається в низці незворотних дій, що ідуть від мене й ціннісно утверджують іншу людину в моментах його зовнішньої завершеності: обійми, поцілунок, осінення («осенение») і таке ін.» 
лише в одному місці, але п'ять разів на один абзац загалом за контекстом у значенні формотворення образу іншого (образу душі в тілі). У словнику Даля слово «осенять», «осенить» зустрічається у восьми словникових статтях і всюди лише в одному словосполученні «осіняти хрестом» («осенить крестом») і відповідно в значенні «хрестити» ${ }^{10}$. Отже, в іншому значенні Бахтін це слово вживати не міг. При цьому частота його вживання доводить настійну потребу в цьому слові, яка виражається навіть у новоутворенні іменника, якого в російській мові немає. Тобто це слово тут $є$ не просто стилістичним синонімом, а принципово важливим концептом. Відтак естетична діяльність тут мислиться у тісному поєднанні з релігійним жестом хрещення. I, зважаючи на те, що (див. першу цитату в примітці) йдеться про естетичну активність не стільки в мистецтві, скільки насамперед у житті, відкритій події буття, то цей зв'язок мислиться, сказати б, генетично (що є цілком протилежним позиції Когена, як було показано вище).

Відтак естетична діяльність постає певною мірою як аналог релігійного спасіння: «Естетично творче відношення до героя та його світу є відношення до нього - як до того, хто має померти (moriturus), протиставлення його смисловій напрузі рятівного завершення» [Бахтин, 2003: с. 248] ${ }^{11}$.

Прикметним є той факт, що в естетиці Бахтіна, попри незаперечну наявність релігійних мотивів, відсутні (на відміну від Когена) прямі звернення до питання про зв'язок між релігією та мистецтвом, намагання прямо його визначити, як це мало місце в німецького філософа. Особливо за тієї обставини, що і в Когена, і в Бахтіна спостерігається співвіднесеність трьох ідей: естетичної любові, завершення і зв'язку мистецтва з релігією, - причому перші дві Бахтін запозичив у Когена, третя ж в останнього виявляє себе під знаком заперечення, а у Бахтіна - під знаком безперечного утвердження, але непрямо, без загальної постановки питання, тобто без загальних дефініцій. На тлі Когена ця відмова виглядає свідомим рішенням. Нам здається логічним припустити (звісно, тут мова може йти лише про припущення), що саме ствердна позиція Бахтіна в цьому питанні й є причиною відсутності прямої його постановки, оскільки це виходить за межі наукового розгляду.

Отже, запозичуючи когенівську понятійну конфігурацію, Бахтін піддає іiі радикальному переакцентуванню й переосмисленню відповідно до принципових засад своєї

«Зовнішнє, обмежене буття іншого, - як предмет обіймів, цілування, осінення, - стає ціннісно пружним і важким...»; «...ми відволікаємося тут від сексуальних моментів, що замутнюють естетичну чистоту цих незворотних дій, ми беремо їх як художньо-символічні життєві реакції на ціле людини, коли ми, обіймаючи або осінюючи тіло, обіймаємо або осінюємо й душу, що в ньому замкнена [заключенную в нем] і яку воно виражає» [Бахтин, 2003: с. 120].

10 Те саме значення має українське слово «осінити», «осіняти», як вказують академічні словники української мови [Етимологічний словник, 2003: с. 221; Словник, 1974: с. 766]. Цікаво, що в словнику Ожегова цього слова взагалі немає, а натомість, згідно зі «Словником української мови», воно продовжувало своє життя у XX столітті. Важливо зазначити, що авторитетний словник Єфремова-Кримського російське «осенять» у перекладається зазвичай як «обтіняти», «окривати»; у значенні «осенять крестом» - «знаменувати», «оклоняти».

11 Лексика, пов'язана з релігійною цариною, зокрема, з темою спасіння, можна сказати, пронизує характеристику естетичної діяльності, надає їй проникливості й без перебільшення навіть містичної глибини. Естетична активність з боку героя в деяких місцях бахтінського тексту тлумачиться як «естетична благодать», «милість» [Бахтин, 2003: с. 141, 152-153] і зрештою прямо як «естетичне спасіння»: «У трагедії в іiї цілому як художній події активним $є$ авторспоглядач, а герої - пасивними, вони потребують спасіння, мають бути спокутані естетичним спасінням» [Бахтин, 2003: с. 146]. 
першої філософії, феноменології події буття. Відтак філософія і естетика Бахтіна постає не просто як переосмислення окремих положень філософії й естетики Когена, але як перехід на принципово інші філософські засади - від трансцендентальної філософії свідомості до філософії буття. А в естетиці він переходить від розгляду естетичної свідомості до естетичної події, що розгортається між двома свідомостями.

\section{СПИСОК ЛІТЕРАТУРИ}

Бахтин (2003): Бахтин, М. М. Собрание сочинений: В 7-ми тт.; Т. 1: Философская эстетика 1920-х годов. Москва: Русские словари; Языки славянской культуры, 2003, 960 с.

Бонецкая (1994): Бонецкая, Н.К. «М. Бахтин в 1920-е годы». В: Диалог. Карнавал. Хроноmon, 1994, № 1, С. 16-62.

Етимологічний словник (2003): Етимологічний словник української мови: У 7 тт.; Т. 4: Н-П. Київ: Наукова думка, 2003, 656 с.

Исупов (1990): Исупов, К. Г. «О философской антропологии М.М. Бахтина». В: Бахтинский сборник, Вып. І: Сб. ст. Москва: Прометей, 1990, С. 30-46.

Исупов (2010): Исупов, К. Г. Судьбы классического наследия и философско-эстетическая культура Серебряного века. Санкт-Петербург: Русская христианская гуманитарная академия, 2010, $592 \mathrm{c.}$

Каган (1991): Каган, М.С. «Идея диалога в философско-эстетической концепции М. Бахтина: закономерности формирования, духовный контекст и социокультурный смисл». В: М.М. Бахтин и философская культура XX века (Проблемы бахтинологии), Вып. 1, Часть 1. Санкт-Петербург: Образование, 1991, С. 17-31.

Каган (2010): Каган, Ю.М. Люди не нашего времени. Михаил Михайлович Бахтин. Москва: РОССПЭН, 2010, С. 34-46.

Пул (1997): Пул, Б. «Роль М.И. Кагана в философии М.М. Бахтина (от Германа Когена к Максу Шелеру)». В: Бахтинский сборник. Выпуск 3. Отв. ред. В.Л. Махлин. Москва: Лабиринт, 1997, С. 162-181.

Пуль (1995): Пуль, Б. «“Назад к Кагану”». В: Диалог. Карнавал. Хронотоп, 1995, № 1(10), C. $38-48$.

Словник (1974): Словник української мови, т. 5: Н-О. Київ: Наукова думка, 1974, 840 с.

Сокулер (2008): Сокулер, З.А. Герман Коген и философия диалога. Москва: ПрогрессТрадиция, 2008, $312 \mathrm{c.}$

Столович (1989): Столович, Л.Н. «М.М. Бахтин и проблема ценности». В: Эстетика М.M. Бахтина и современность. Саранск: Изд. Морд. ГУ, 1989, С. 25-27.

Фохт (2003): Фохт, Б.А. Избранное (из философского наследия). Москва: ПрогрессТрадиция, 2003, $456 \mathrm{c.}$

Фридман (1992): Фридман, И.Н. «Незавершенная судьба естетики завершения». В: М.M. Бахтин как философ. Москва: Наука, 1992, С. 51-67.

Яковенко (1910): Яковенко, Б. «О теоретической философии Германа Когена». В: Логос. Книга первая. Москва: Мусагет, 1910, С. 199-249.

Brandist (2002): Brandist, C. The Bakhtin Circle: Philosophy, Culture and Politics. London: Pluto Press, 2002, $221 \mathrm{p}$.

Clark (1984): Clark, K., Holquist, M. Mikhail Bakhtin. Cambridge, Mass.: Belknap Press of Harvard UP, 1984, $398 \mathrm{p}$.

Coates (1999): Coates, R. Christianity in Bakhtin: God and the Exiled Author (Cambridge Studies in Russian Literature). Cambridge, Eng.; New York, US: Cambridge UP, 1999, (xiv) 204 p.

Holquist (2002): Holquist, M. Dialogism. Bakhtin and his World. London \& NY: Routledge, 2002, $224 \mathrm{p}$.

Cohen (1889): Cohen, H. Kants Begründung der Aesthetik. Berlin: Ferd. Dümllers Verlagsbuchhandlung, 1889, $434 \mathrm{~S}$.

Cohen (1912): Cohen, H. System der Philosophie. T. 3: Ästhetik des reinen Gefühls, Bd. 1, Berlin: Cassirer, 1912, xiv, $402 \mathrm{~S}$. 
Copleston (1994): Copleston, F.A History of Philosophy. Volume 7: Modern Philosophy, from the Post-Kantian Idealists to Marx, Kierkegaard, and Nietzsche. New York: Image Books, 1994, $496 \mathrm{p}$.

Poma (1997): Poma, A. The Critical Philosophy of Hermann Cohen. Albany: SUNY Press, 1997, $320 \mathrm{p}$.

Poma (2006): Poma, A. Yearning for Form and Other Essays on Hermann Cohen's Thought, Dordrecht: Springer, 2006, xiii, 388 p.

Renz (2003): Renz, U. Critical Idealism and the Concept of Culture. Hermann Cohen's Critical Idealism. Ed. by Reinier Munk. Dordrecht: Springer Science \& Business Media, 2006, P. 327-356.

Стаття одержана редакцією 11.06 .2014

\section{REFERENCES}

Bakhtin, M.M. Works: in 7 vol, Vol. 1: Philosophical Aesthetics of 1920s. [In Russian]. Moscow: Publishing House Russian Dictionaries; Languages of Slavic Culture, 2003, 960 p. [= Бахтин, 2003]

Bonetskaya, N.K. «M. Bahktin in $1920^{\text {th }} »$. [In Russian]. In: Dialogue. Carnival. Chronotop, 1994, № 1, Р. 16-62. [= Бонецкая, 1994]

Brandist, C. The Bakhtin Circle: Philosophy, Culture and Politics. London: Pluto Press, 2002, 221 p. [= Brandist, 2002]

Clark, K., Holquist, M. Mikhail Bakhtin. Cambridge, Mass.: Belknap Press of Harvard UP, 1984, 398 p. [= Clark, 1984]

Coates, R. Christianity in Bakhtin: God and the Exiled Author (Cambridge Studies in Russian Literature). Cambridge, Eng.; New York, US: Cambridge UP, 1999, (xiv) 204 p. [= Coates, 1999]

Cohen, H. Kants Begründung der Aesthetik. Berlin: Ferd. Dümllers Verlagsbuchhandlung, 1889, 434 S. [= Cohen, 1889]

Cohen, H. System der Philosophie. T. 3: Ästhetik des reinen Gefühls, Bd. 1. Berlin: Cassirer, 1912, (xiv) 402 S. [ = Cohen, 1912]

Copleston, F.A History of Philosophy. Volume 7: Modern Philosophy, from the Post-Kantian Idealists to Marx, Kierkegaard, and Nietzsche. New York: Image Books, 1994, 496 p. [= Copleston, 1994]

Dictionary of Ukrainian Language, Vol. 5. [In Ukrainian]. Kyiv: Naukova Dumka (Scientific Thought), 1974, 840 p. [= Словник, 1974]

Etymological Dictionary of Ukrainian Langauge: in 7 vol. Vol. 4: H-П. Kyiv: Naukova Dumka (Scientific Thought), 2003, 656 р. [= Етимологічний словник, 2003]

Fokht, B.A. Selected Works (from Philosophical Leacy). [In Russian]. Moscow: ProgressTradition, 2003, 456 p. [= Фохт, 2003]

Fridman, I.N. "The Unfinished Fate of "Aesthetics of Completement"». [In Russian]. In: M.M.Bakhtin as a Philosopher. Moscow: Nauka, 1992, P. 51-67. [= Фридман, 1992]

Isupov, K.G. «About the Philosophical Anthropology of M. M. Bakhtin». In: Bakhtin's Collection. Vol. I. [In Russian]. Moscow: Prometheus, 1990, P. 30-46. [= Исупов, 1990]

Isupov, K.G. The Fates of Classical Legacy and Philosophic and Aesthetic Culture of the Siler Age. [In Russian]. St. Petersburg: Russian Christian Humanitarian Academy, 2010, 592 p. [= Исупов, 2010]

Kagan, M.S. «The Idea of Dialogue in M. Bakhtin's Philosophic and Aesthetic Conception: Logic of Formation, Spiritual Context and Socio-cultural Sense». [In Russian]. In: M. M. Bakhtin and the Philosophic Culture of XXth century (Problems of Bakhtinology). Vol. 1, Part 1. St. Petersburg: Obrazovanie (Education), 1991, P. 17-31. [= Каган, 1991]

Kagan, Y.M. «Not the People of Our Time». [In Russian]. In: Mikhail Mikhailovoch Bakhtin. Moscow: ROSSPEN, 2010, P. 34-46. [= Каган, 2010] 
Poma, A. The Critical Philosophy of Hermann Cohen. Albany: SUNY Press, 1997, 320 p. [= Poma, 1997]

Poma, A. Yearning for Form and Other Essays on Hermann Cohen's Thought. Dordrecht: Springer, 2006, (xiii) 388 p. [= Poma, 2006]

Poole, B. «"Back to Kagan”». [In Russian]. In: Dialogue. Carnival. Chronotope, 1995, № 1(10), Р. 38-48. [= Пуль, 1995]

Poole, B. «The M. I. Kagan's Role in M. M. Bakhtin's Philosophy (from Hermann Cohen to Max Scheller)». [In Russian]. In: Bakhtin's Collection. Vol. 3. Moscow: Labirinth, 1997, P. 162181. [= Пуль, 1991]

Renz, U. Critical Idealism and the Concept of CultureHermann. Cohen's Critical Idealism. Ed. by Reinier Munk. Dordrecht: Springer, 2006, P. 327-356. [= Renz, 2006]

Sokuler, Z.A. Hermann Cohen and the Philosophy of Dialogue. [In Russian]. Moscow: ProgressTradition, 2008, 312 p. [= Сокулер, 2008]

Stolovich, L.N. «M. M. Bakhtin and the Problem of Value». In: M.M. Bakhtin's Aesthetics and Modernity. [In Russian]. Saransk: Ogarev Mordovia State University Press, 1989, P. 25-27. [= Столович, 1989]

Yakovenko, B. «On Hermann Cohen's Theoretical Philosophy». [In Russian]. In: Logos. Book One. Moscow: Musaget, 1910, Р. 199-249. [= Яковенко, 1910]

Received 11.06.2014

\section{Alexander Yudin}

\section{The Aesthetics of Hermann Cohen and the Aesthetics of Mikhail Bakhtin: Conceptual Borrowings and their Rethinking}

The article deals with the comparative analysis of philosophic and aesthetic positions of H. Cohen and early M. M. Bakhtin. It considers in detail the place of configuration of concepts of completion and aesthetic love (borrowed by Bakhtin from Gohen's aesthetics) in the aesthetics of each thinker. It shows the radical rethinking of the meaning and contents of these notions and reaccentuating their place in Bakhtin's aesthetics particularly on connection with the question of relation between art and religion where thinkers take opposed positions, and also in connection with general Bakhtin's philosophic provisions, treating being as interaction between two consciousnesses. It si concluded that this rethinking conditioned by Bakhtin's surmounting of transcendental approach in philosophy and going over from philosophy of consciousness to philosophy of being, and in aesthetics - from aesthetics of consciousnesses to aesthetics of event.

Alexander Yudin, PhD in philology, docent at the Department of Russian and foreign literature, Foreign Philology Institute of National Pedagogical Dragomanov University(Kyiv),

Олександр Юдін, кандидат філологічних наук, дочент кафедри російської та зарубіжної літератури Національного педагогічного університету ім. М. П. Драгоманова (Київ)

Александр Юдин, кандидат филологических наук, дочент кафедры русской и зарубежной литературы Национального педагогического университета им. М. П. Драгоманова (Киев)

e-mail: alexayu@mail.ru 